\title{
Legionella taurinensis sp. nov., a new species antigenically similar to Legionella spiritensis
}

\author{
François Lo Presti, ${ }^{1}$ Serge Riffard, ${ }^{1}$ Helene Meugnier, ${ }^{1}$ \\ Monique Reyrolle, ${ }^{1}$ Yves Lasne, ${ }^{2}$ Patrick A. D. Grimont, ${ }^{3}$ \\ Francine Grimont, ${ }^{3}$ François Vandenesch, ${ }^{1}$ Jerome Etienne, ${ }^{1}$ \\ Jean Fleurette ${ }^{1}$ and Jean Freney ${ }^{1}$
}

Author for correspondence: François Lo Presti. Tel: +334787786 57. Fax: +33478778658. e-mail: derba@laennec.univ-lyonl.fr

\footnotetext{
1 Centre National de Référence des Legionella UPRES EA1655, Faculté de Médecine R.T.H. Laennec, 69372 Lyon cedex 08, France

2 Laboratoire des Radioisotopes et de Biochimie Moléculaire, Hôpital Edouard Herriot, 69437 Lyon cedex 03 , France

3 Unité des Entérobactéries, Institut Pasteur, 75724 Paris cedex 15, France
}

\begin{abstract}
A group of 42 Legionella-like organisms reacting specifically with Legionella spiritensis serogroup 1 antisera were collected throughout Europe by the Centre National de Référence (French National Reference Centre) for Legionella. This group of isolates differed somewhat from $L$. spiritensis in terms of biochemical reactions, ubiquinone content and protein profile. The latter two analyses revealed that one of these $L$. spiritensis-like isolates, Turin $I$ no. 1', was highly related, but not identical to any of the red autofluorescent species of Legionella. In fact, this strain was the first of these particular isolates recognized to emit a red autofluorescence when exposed to UV light. Profile analysis of randomly amplified polymorphic DNA established that the red autofluorescent $L$. spiritensis-like isolates constituted a homogeneous group distinct from Legionella rubrilucens and Legionella erythra. DNA-DNA hybridization studies involving the use of S1 nuclease confirmed that the indicated group of isolates are a new species of Legionella, for which the name Legionella taurinensis is proposed with strain Turin I no. ${ }^{\top}$ (deposited as ATCC 700508') as the type strain.
\end{abstract}

Keywords: Legionella taurinensis sp. nov., taxonomy, identification

\section{INTRODUCTION}

Bacteria of the family Legionellaceae are usual inhabitants of both natural and man-made aquatic habitats (Fliermans, 1996; Fliermans et al., 1981; Stout et al., 1985). Their survival in these environments is highly dependent on their ability to invade and multiply within a large diversity of protozoa (Fields, 1996; Rowbotham, 1980). Since the description of this family in 1979 (Brenner et al., 1979), 42 species represented by 64 serogroups have been described including Legionella lytica, a species not yet culturable on buffered charcoal-yeast extract (BCYE) media (Benson et al., 1996; Hookey et al., 1996). Other strains of Legionellalike amoebal pathogens (LLAP) that are not yet culturable could presumably add five more species to the genus Legionella (Adeleke et a, 1996). Twenty-

Abbreviations: DFA, direct immunofluorescence assay; LLAP, Legionellalike amoebal pathogens; RAPD, randomly amplified polymorphic DNA.

The GenBank accession number for the sequence reported in this paper is AF037597. five of the Legionella species were initially described on the isolation of a single unidentified strain and some of them are still represented (to our knowledge) by the original strain only (Benson et al., 1991, 1996; Bornstein et al., 1989; Brenner et al., 1985; Dennis et al., 1993; Edelstein et al., 1982; Herwaldt et al., 1984; Thacker et al., 1988, 1989, 1992; Verma et al., 1992; Wilkinson et al., 1987, 1988). Legionella pneumophila remains the most frequently isolated species from patients, although eighteen other species, including $L$. lytica, have also been isolated in these instances from pneumonia patients (Hookey et al., 1996; Lo Presti et al., 1997). Some species, such as Legionella parisiensis, Legionella gormanii and Legionella jordanis were first obtained as environmental specimens before being recognized as human pathogens.

During several recent investigations of hospital and community water in Europe, 42 isolates reacting exclusively with antisera raised against $L$. spiritensis serogroup 1 were collected by the Centre National de Référence des Legionella (French National Reference Centre for Legionella). However, in contrast to $L$. 
spiritensis, some of these isolates displayed red autofluorescence under longwave UV light. This unusual feature stimulated the characterization of this group of organisms. Analysis of phenotypic and genotypic characteristics presented in this report have led to the description of this group as a new species, Legionella taurinensis.

\section{METHODS}

Isolation procedure. Water samples (1 1) were collected from six European countries (Czech Republic, France, Italy, Portugal, Spain and Switzerland), concentrated by continuous centrifugation and/or filtration, and either untreated or treated by acidification according to previously described procedures (Bornstein et al., 1989). All samples were cultured on BCYE agar supplemented with $0.1 \% \alpha$ ketoglutarate $(\mathrm{BCYE} \alpha)$ and $\mathrm{BCYE} \alpha$ supplemented with glycine, vancomycin and colistin (GVC).

Bacterial strains. Forty-two isolates of Legionella (Table 1) were obtained from the different sites. In addition, the type strains of 41 Legionella species (Table 2) were used in this study; these strains fell into 63 serogroups. Several potential new species, including 'Legionella donaldsonii' (strain 'Glasgow' 86/35784; gift from T. G. Harrison, Colindale, UK) (Hookey et al., 1996), which has not yet been formally described, were also tested (Table 2). As amoebal cultures were not available, one validly published species, $L$. lytica, could not be used for the DNA hybridization studies.

Cultural and biochemical tests. The type strains and the isolates were cultured on BCYE $\alpha$ or GVC when needed. Requirement for cysteine was tested by its omission when preparing the BCYE $\alpha$ media. The cultures were examined for autofluorescence using Wood's light ( $366 \mathrm{~nm})$. Tests for catalase, oxidase, $\beta$-lactamase, hippurate hydrolysis, urease, glucose fermentation, gelatinase, nitrate reduction and the presence of flagella were done as previously described (Brenner et al., 1985). Browning of tyrosine-supplemented agar was considered positive if the browning produced around the colonies was larger on tyrosine-supplemented agar than any browning produced around the colonies of the same strain on tyrosine-free agar after 3 d growth (Vickers \& $\mathrm{Yu}, 1984)$. The colour of the colonies was also noted on DGVC agar plates, which is a GVC media modified by the addition of dyes (bromocresol purple and bromothymol blue) allowing a visual differentiation between Legionella micdadei, Legionella maceachernii (colonies are blue) and the other species of Legionella (colonies are green) (Vickers $e t$ al., 1987).

Direct immunofluorescence assays. The 42 Legionella isolates collected from different sites were identified by performing direct immunofluorescence assays (DFA) using 59 hyperimmune rabbit antisera prepared as previously described (Cherry et al., 1978). Antisera were not available for four species: Legionella genomospecies 1, Legionella lansingensis, Legionella shakespearei and Legionella waltersii. Conversely, all of the 63 serogroup reference strains were tested by DFA using an antiserum prepared against strain Turin I no. $1^{\mathrm{T}}$, the first red autofluorescent isolate, designated as the type strain (ATCC $700508^{T}$ ) of a group of such isolates referred to as cluster 'Turin'.

Cell wall fatty acids, isoprenoid quinone composition and protein profile analysis. Cell wall fatty acids and isoprenoid quinones were assayed as previously described (Lambert \& Moss, 1989) for bacteria grown on BCYE $\alpha$ agar plates for $48-96 \mathrm{~h}$ at $37^{\circ} \mathrm{C}$. The protein electrophoretic patterns of 11 isolates (Turin I no. $1^{\mathrm{T}}$, Turin I no. 2, Turin II no. 180, Turin II no. 195, Madrid IV no. 1, Châlons/Saône eau 1 colonie 25, Hôtel-Dieu 2 B3, Lausanne 15 no. 6, St-Etienne III no. 1, Lisbonne III A5 and Toulouse 26 no. 14) were compared between isolates and with other species, namely Legionella erythra (both serogroups), L. spiritensis serogroup 1 and Legionella rubrilucens, after SDS-PAGE analysis according to a previously described technique (Bornstein et al., 1989).

Genotypic characterization. DNA was extracted by the boiling water method (Gomez-Lus et al., 1993) and purified by phenol-chloroform-isoamyl alcohol $(25: 24: 1)$, followed by ethanol precipitation. Randomly amplified polymorphic DNA (RAPD) analysis was performed with primer SK2 (5' CGGCGGCGGCGG 3') (Meunier \& Grimont, 1993) as previously described (Lo Presti et al., 1997).

165 rDNA amplification and sequencing. DNA amplification of the $16 \mathrm{~S}$ rRNA gene of the strain Turin I no. $1^{\mathrm{T}}$ was performed with oligonucleotide primers L16Al ( $5^{\prime}$ AGA GTT GGA TCC TGG CTC AG $3^{\prime}$ ) and L16r1488 (5' GAC TTC ACC CCA GTC ATG AA 3'), corresponding to positions 8-27 and 1488-1508, respectively, in the Escherichia coli numbering system (Brosius et al., 1978). Sequencing was done by the dideoxy chain-termination method (Sanger et al., 1977) under previously described conditions (Lo Presti

Table 1. L. taurinensis strains

\begin{tabular}{|c|c|c|}
\hline Origin & No. of isolates & Strain \\
\hline Czech Republic & 1 & BM-750 \\
\hline France & 24 & $\begin{array}{l}\text { Châlons/Saône eau } 1 \text { colonie } 25 \text {, Châlons/Saône eau } 1 \text { colonie 26, Croix-Rousse } 2 \text { C9, } \\
\text { Croix-Rousse } 2 \text { C13, Gap I B 41, Gap I B42, Hôtel-Dieu } 2 \text { B3, Hôtel-Dieu } 2 \text { B4, Hôtel- } \\
\text { Dieu } 2 \text { B12, Henry-Gabrielle I eau } 1 \text { C7, Henry-Gabrielle I eau } 3 \text { C7, Henry-Gabrielle I } \\
\text { eau } 3 \text { C10, IB } 39 \text { no. 6, Moulins I C1, Moulins I D3, Moulins I D5, Moulins I D6, } \\
\text { Mercure } 96 \text { I eau } 8 \text { no. } 7 \text {, Mercure } 96 \text { I eau } 8 \text { ng. 8, St-Etienne III no. 1, Toulouse } 26 \\
\text { no. } 14 \text {, Toulouse } 26 \text { no. } 17 \text {, Toulouse } 28 \text { no. } 7 \text {, Toulouse } 28 \text { no. } 8\end{array}$ \\
\hline Italy & 4 & Turin I no. $1^{\mathrm{T}}$ (ATCC $700508^{\mathrm{T}}$ ), Turin I no. 2, Turin II no. 180 , Turin II no. 195 \\
\hline Portugal & 8 & $\begin{array}{l}\text { Lisbonne III A5, Portugal A12, Portugal A13, Portugal A14, Portugal A16, Portugal } \\
\text { A17, Portugal A19, Portugal A20 }\end{array}$ \\
\hline Spain & 2 & Madrid I no. 4, Madrid IV no. 1 \\
\hline Switzerland & 3 & Genève 10 no. 1 , Lausanne 15 no. 6 , Lausanne $96 \mathrm{~V}$ no. 1 \\
\hline
\end{tabular}


Table 2. $16 \mathrm{~S}$ rRNA similarity and DNA relatedness of strain Turin I no. $1^{\top}$

\begin{tabular}{|c|c|c|c|c|}
\hline \multirow[t]{4}{*}{ Source of unlabelled DNA (Legionella strain) } & \multicolumn{3}{|c|}{ Relatedness (\%) to labelled DNA from: } & \multirow{4}{*}{$\begin{array}{c}\text { Similarity }(\%) \text { to } 16 \mathrm{~S} \\
\text { rDNA gene of Turin I } \\
\text { no. } 1^{\mathrm{T}}\end{array}$} \\
\hline & \multicolumn{2}{|c|}{ Turin I no. $1^{\mathrm{T}}$ (ATCC 700508 $)$} & \multirow{3}{*}{$\frac{\begin{array}{c}\text { L. rubrilucens } \\
\left(\text { ATCC } 35304^{T}\right)\end{array}}{60^{\circ} \mathrm{C}}$} & \\
\hline & $60^{\circ} \mathrm{C}^{*}$ & $\Delta T_{\mathrm{m}}^{\dagger}$ & & \\
\hline & & & & \\
\hline Turin I no. $1^{\mathrm{T}} \ddagger$ & 100 & 0.0 & 54 & $100 \cdot 0$ \\
\hline Turin I no. $2 \ddagger$ & 100 & $0 \cdot 0$ & ND & \\
\hline Lisbonne III A5 $\ddagger$ & 95 & $0 \cdot 0$ & ND & \\
\hline Madrid IV no. $1 \ddagger$ & 78 & $2 \cdot 5$ & 56 & \\
\hline L. rubrilucens (ATCC 35304 ) & 64 & $7 \cdot 5$ & 100 & $99 \cdot 03-99 \cdot 1$ \\
\hline L. erythra serogroup 2 (LC 217) & 47 & & & \\
\hline L. erythra serogroup 1 (ATCC $\left.35303^{\mathrm{T}}\right)$ & 36 & & & 98.44 \\
\hline L. spiritensis serogroup 2 (NCTC 12082) & 25 & & & \\
\hline L. spiritensis serogroup $1\left(\right.$ ATCC $\left.35249^{\mathrm{T}}\right)$ & 19 & & & $95 \cdot 8$ \\
\hline L. cherrii $\left(\mathrm{ATCC} 35252^{\mathrm{T}}\right.$ ) & 18 & & & $92 \cdot 4$ \\
\hline L. birminghamensis (ATCC $43702^{\mathrm{T}}$ ) & 16 & & & $95 \cdot 1$ \\
\hline 'L. donaldsonii' (strain LC 878) & 15 & & & $95 \cdot 0$ \\
\hline L. jordanis (ATCC 33623') & 15 & & & $94 \cdot 1$ \\
\hline L. pneumophila serogroup $1\left(\right.$ ATCC $\left.33152^{\mathrm{T}}\right)$ & 14 & & & $95 \cdot 0$ \\
\hline L. israelensis (ATCC $43119^{T}$ ) & 13 & & & $92 \cdot 7$ \\
\hline L. micdadei (ATCC $33218^{\mathrm{T}}$ ) & 13 & & & $94 \cdot 6$ \\
\hline L. geestiana (ATCC 49504 $)$ & 9 & & & $92 \cdot 4$ \\
\hline L. feeleii serogroup 1 (ATCC $35072^{\mathrm{T}}$ ) & 8 & & & $95 \cdot 3$ \\
\hline L. maceachernii (ATCC $35300^{\mathrm{T}}$ ) & 8 & & & $93 \cdot 9$ \\
\hline L. adelaidensis (ATCC 49625') & 7 & & & $94 \cdot 1$ \\
\hline L. bozemanii serogroup $1\left(\right.$ ATCC $\left.33217^{\mathrm{T}}\right)$ & 7 & & & $94 \cdot 7$ \\
\hline L. brunensis (ATCC $43878^{\mathrm{T}}$ ) & 7 & & & $95 \cdot 2$ \\
\hline L. londiniensis (ATCC 49505 $)$ & 7 & & & $93 \cdot 6$ \\
\hline L. nautarum (ATCC $49506^{\mathrm{T}}$ ) & 7 & & & $94 \cdot 3$ \\
\hline L. hackeliae serogroup 1 (ATCC $35250^{\mathrm{T}}$ ) & 6 & & & $95 \cdot 0$ \\
\hline L. longbeachae serogroup 1 (ATCC $\left.33462^{\mathrm{T}}\right)$ & 6 & & & 94.7 \\
\hline L. oakridgensis (ATCC $33761^{\mathrm{T}}$ ) & 6 & & & $93 \cdot 7$ \\
\hline L. fairfieldensis (ATCC $49588^{\mathrm{T}}$ ) & 5 & & & $95 \cdot 7$ \\
\hline L. lansingensis $\left(\mathrm{ATCC} 49751^{\mathrm{T}}\right)$ & 5 & & & $93 \cdot 0$ \\
\hline L. anisa (ATCC $\left.35292^{\mathrm{T}}\right)$ & 4 & & & $94 \cdot 1$ \\
\hline Other Legionella species§ & $<3$ & & & $<95 \cdot 3$ \\
\hline LLAP strains & ND & & & $<95.0$ \\
\hline
\end{tabular}

${ }^{*}$ Reactions were done at least in duplicate at $60^{\circ} \mathrm{C}$.

$\dagger$ Divergence from the $T_{m}$ of Turin I no. $1^{\mathrm{T}}\left(\right.$ ATCC $\left.700508^{\mathrm{T}}\right)$, calculated to the nearest $0.5 \%$. Reactions were done in triplicate. $\ddagger$ Strains of the cluster 'Turin'.

§Other Legionella species: Legionella cincinnatiensis, ATCC $43753^{\mathrm{T}}$; Legionella dumoffii, ATCC $33279^{\mathrm{T}}$; Legionella genomospecies 1 , ATCC $51913^{\mathrm{T}}$; Legionella gormanii, ATCC $33297^{\mathrm{T}}$; Legionella gratiana, ATCC $49413^{\mathrm{T}}$; Legionella jamestowniensis, ATCC $35298^{\mathrm{T}}$;

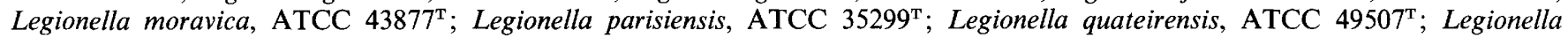
quinlivanii serogroup 1, ATCC 43830 ${ }^{\mathrm{T}}$; Legionella sainthelensi serogroup 1, ATCC $35248^{\mathrm{T}}$; Legionella santicrucis, ATCC $35301^{\mathrm{T}}$; Legionella shakespearei, ATCC 49655 ; Legionella steigerwaltii, ATCC $35302^{\mathrm{T}}$; Legionella tucsonensis, ATCC $49180^{\mathrm{T}}$; Legionella wadsworthii, ATCC $33877^{\mathrm{T}}$; L. waltersii, ATCC $51914^{\mathrm{T}}$; Legionella worsleiensis, ATCC $49508^{\mathrm{T}}$; strain Greoux 11 D13, ATCC 700509; and strain IB V no. 2, ATCC 700511.

ND, Not determined.

et al., 1997), and the sequence (GenBank no. AF037597) was compared with those previously published (Adeleke et al., 1996; Birtles et al., 1996; Fry et al., 1991; Hookey et al., 1996) and available in the DDBJ, EMBL and GenBank databases with the gapped BLAST program (Altschul et al., 1997) via the Internet (http://www.ncbi.nlm.nih.gov).
DNA studies. DNA was extracted and purified as previously described (Brenner et al., 1982) and the native DNA was labelled by nick-translation with ${ }^{3} \mathrm{H}$-labelled nucleotides (Amersham). DNA-DNA hybridization with all species (Table 2) was performed by the standard S1 nuclease method (Grimont et al., 1980). The thermal stability of heterologous 
hybrids was calculated by a standard method (Crosa et al., 1973).

The $\mathrm{G}+\mathrm{C}(\mathrm{mol} \%)$ content of DNA from strain Turin I no. $1^{\mathrm{T}}$ was determined by HPLC of nucleotides after hydrolysis of the DNA by P1 nuclease (Kaneko et al., 1986) and also spectrophotometrically by the thermal denaturation method (Marmur \& Doty, 1962).

\section{RESULTS}

\section{Cultural and biochemical characterization}

The 42 strains of the 'Turin' cluster of Legionella collected from hospital and community water in Europe grew on BCYE $\alpha$ agar and GVC medium, but not on blood agar or BCYE $\alpha$ lacking supplemented Lcysteine. The type strain, Turin I no. $1^{\mathrm{T}}$, was a Gramnegative rod with a single polar flagellum. Physiological tests performed on the cluster were positive for gelatin liquefaction and the presence of flagella $(100 \%$ of isolates), catalase (93\%), $\beta$-lactamase $(98 \%)$ and oxidase $(76 \%)$. Negative reactions were obtained for urease, carbohydrate fermentation and nitrate reduction. The majority of isolates $(90 \%)$ did not hydrolyse hippurate. No brown pigment was produced on tyrosine-supplemented media by the majority of these strains $(96 \%)$ when using the 3 d growth criteria. After $10 \mathrm{~d}$ growth, $67 \%$ of the isolates remained negative while half of the positive strains were detected as only weakly positive. Including the type strain (at the first isolation), $67 \%$ of the strains exhibited red autofluorescence under UV light whereas the other isolates were not autofluorescent or produced only a weak red autofluorescence after two subcultures. However, this autofluorescence was often lost after several passages on agar media; this situation is similar to that observed for the bluish-white autofluorescent species of Legionella (unpublished observations). All the isolates also gave rise to yellow fluorescence of the growth medium. Colonies produced a greenish colour on DGVC medium. Strain Madrid IV no. 1 turned out to be the most divergent strain of the cluster in terms of biochemical reactions (e.g. oxidase-negative, production of brown pigment on tyrosine-supplemented media).

\section{DFA}

Isolate Turin I no. $1^{\mathrm{T}}$ and the 41 other members of the 'Turin' cluster gave a $3+$ to $4+$ fluorescence with $L$. spiritensis serogroup 1 antisera. Antisera developed against the Turin I no. $1^{\mathrm{T}}$ isolate gave a $4+$ fluorescence with the homologous strain and $3+$ with the L. spiritensis type strain. The cross-reaction could not be abolished by absorption with $L$. spiritensis.

\section{Cellular fatty acids and ubiquinone composition}

The Turin I no. $1^{\mathrm{T}}$ isolate and members of this group contain the 14-methylpentadecanoic acid (i16:0) which accounts for more than $20 \%$ of the fatty acid composition; this is followed by 10-20\% 12-methyltetradecanoate (a15:0), cis-9-hexadecenoate (16:1) and hexadecanoate (16:0). The branched-chain fatty acid 14-methylhexadecanoate (a17:0) accounts for $10 \%$ and the $114: 0$ for $3 \%$; only minor quantities of $15: 1$, heptadecanoate $(17: 0)$ and octadecanoate $(18: 0)$ were found. In comparison, the Madrid IV no. 1 isolate, the most divergent strain of this cluster, had less a15:0 (1\%) and more a17:0 (21\%). The ubiquinone profiles of 'Turin' cluster isolates were dominated by the presence of quinone Q-12. Ubiquinones Q-11 and Q-13 each accounted for approximately $20 \%$ of the amount of Q-12.

\section{Protein profiling}

Protein profiles revealed 90-95\% homology for the 11 isolates of cluster 'Turin' tested and a maximum of $86 \%$ homology with $L$. rubrilucens, $83 \%$ with $L$. erythra and $79 \%$ with $L$. spiritensis.

\section{RAPD analysis}

Strains of the cluster 'Turin' showed a unique pattern by RAPD analysis that differed from those obtained for all the 41 other Legionella species tested (data not shown).

\section{Sequencing of the 16S rRNA genes}

The sequence of the 16S rRNA gene of the strain Turin I no. $1^{\text {T }}$ (GenBank no. AF037597) was 99.10\% identical to sequence $\mathrm{X} 73398$ of $L$. rubrilucens, which was the closest sequence, $99.03 \%$ identical to sequence Z32643 of L. rubrilucens, $98.44 \%$ identical to sequence M36027 of L. erythra serogroup 1 and only $95.8 \%$ identical to the $16 \mathrm{~S}$ rRNA gene of $L$. spiritensis serogroup 1 . The sequence was less than $95 \%$ related to each of the $16 \mathrm{~S}$ rDNA sequences of the LLAP strains (including L. lytica).

\section{DNA hybridization}

${ }^{3} \mathrm{H}$-labelled DNA from strain Turin $\mathrm{I}$ no. $1^{\mathrm{T}}$ was hybridized with unlabelled DNAs from type strains of the other Legionella species and three strains of the same cluster (Table 2). Table 2 shows that there was $\geqslant 78 \%$ relatedness between each of the four strains of the cluster 'Turin' with a maximum of $2.5^{\circ} \mathrm{C}$ divergence in thermal stability of the hybrids. In optimal reactions performed at $60^{\circ} \mathrm{C}$, labelled DNA from the strain Turin I no. $1^{\mathrm{T}}$ was $64 \%$ related to the type strain of $L$. rubrilucens. The divergence in thermal stability of this hybrid was $7.5^{\circ} \mathrm{C}$. In the reciprocal reaction, the level of DNA relatedness between the type strain of $L$. rubrilucens and strain Turin I no. $1^{\mathrm{T}}$ fell to $54 \%$. The DNA relatedness obtained with Madrid IV no. 1, the most divergent strain of the cluster 'Turin', was 56\% when it was hybridized to labelled DNA from $L$. rubrilucens.

\section{$\mathbf{G}+\mathbf{C}$ content}

The $\mathrm{G}+\mathrm{C}$ content of strain Turin $\mathrm{I}$ no. $1^{\mathrm{T}}$ was $46 \mathrm{~mol} \%$ by each of the two methods used. 


\section{DISCUSSION}

The red autofluorescence exhibited by the majority of the isolates of the 'Turin' cluster under UV light did not affirm the match with the phenotypic characteristics of $L$. spiritensis with which the cluster appeared to show a potentially strong antigenic relationship. Further biochemical characterization of the 'Turin' cluster isolates revealed that a marked difference existed between the isolates and $L$. spiritensis, L. rubrilucens and L. erythra, in that the isolates of the cluster did not produce the brown pigment on tyrosine-supplemented media. The major fatty acids of the type strain, Turin I no. $1^{\mathrm{T}}$, comprised those with 16 carbon atoms, which is the case for the red autofluorescent species and $L$. spiritensis; however, the isolates of the 'Turin' cluster had more n16:0 than $L$. erythra, L. rubrilucens and L. spiritensis, and less i16:0 than $L$. rubrilucens. Since the differentiation of all these species by fatty acid composition varies according to growth medium, this feature would appear to be more useful for ascribing unknown isolates to groups of species (Wilkinson et al., 1990). The ubiquinone composition of the 'Turin' cluster clearly differentiated it from $L$. spiritensis, which contains ubiquinone Q-13 as major ubiquinone and not quinone Q-12.

Sequencing of the 16S rRNA gene has proved to be a useful tool for assigning an unidentified isolate to the nearest species. Sequence homologies of this gene between the two described red autofluorescent Legionella species (L. rubrilucens and L. erythra) were $99.4 \%$ (Hookey et al., 1996). Comparison of the 16S rRNA gene sequence of the type strain, Turin $I$ no. $1^{\mathrm{T}}$, with those of the $L$. rubrilucens and $L$. erythra species, revealed high similarities ( 99.1 and $98.4 \%$, respectively). This raised the possibility that strain Turin I no. $1^{\mathrm{T}}$ was a subspecies or a new serogroup of $L$. rubrilucens. DNA hybridization ruled out this possibility by showing that strain Turin I no. $1^{\mathrm{T}}$ constitutes a distinct species. It should be noted that DNA hybridization was not possible with the five LLAP groups (since total DNA was not available), but their 16S rDNA sequence had less than $95 \%$ homology with Turin I no. $1^{\mathrm{T}}$ making it very unlikely that strain Turin I no. $1^{\mathrm{T}}$ belonged to any of the LLAP groups (Stackebrandt \& Goebel, 1994).
Recently, the RAPD technique has been used for the identification of a newly described clinical strain, $L$. parisiensis. This approach showed that species-specific profiles could be obtained for the bluish-white autofluorescent Legionella species (Lo Presti et al., 1997). By applying the RAPD technique to the red autofluorescent species and to the 'Turin' cluster, a specific profile for the newly proposed species was produced. This specific profile yielded no common bands with the species-specific profile of $L$. rubrilucens, indicating that the 'Turin' cluster was a homogeneous group differing in genotype from $L$. rubrilucens.

Ultimately, the genetic definition of a species for the 'Turin' cluster (Wayne et al., 1987) was fulfilled by the data obtained from whole DNA-DNA hybridization studies, which manifested a homogeneous group with more than $70 \%$ DNA relatedness between the four tested strains and less than $5{ }^{\circ} \mathrm{C}$ difference between them in thermal stability (Table 2). Moreover, this cluster has less than $70 \%$ relatedness at the DNA level to the closest species, L. rubrilucens, and the thermal stability of the hybrid of these two species differs by more than $7.5^{\circ} \mathrm{C}$. Consequently, both results confirm that the 'Turin' cluster forms the 43rd Legionella species. Thus, the confidence attained in differentiating this new species according to phenotypes from other Legionella species (Table 3) presents the opportunity to formalize the name (Benson et al., 1996; Ursing et al., 1995).

\section{Description of Legionella taurinensis sp. nov.}

Legionella taurinensis (tau.ri.nen'sis. M.L. adj. taurinensis pertaining to Turin, Italy, whose classical Latin name was Augusta Taurinorum)

This bacterium is a Gram-negative rod with a single polar flagellum. It gives positive reactions for catalase, oxidase, gelatinase and the presence of $\beta$-lactamase. Negative reactions are recorded for urease, nitrate reduction, acid production from $\mathrm{D}$-glucose, browning of tyrosine agar and hippurate hydrolysis. Some of the strains autofluoresce red (at $365 \mathrm{~nm}$ ). DFA results exhibit strong cross-reaction with $L$. spiritensis. This species has ubiquinone Q-12 as the major component. All the strains of this species have been isolated from water samples throughout Europe. The type strain of

Table 3. Phenotypic comparison of $L$. taurinensis and three other species

\begin{tabular}{|lccccc|}
\hline Legionella species & Oxidase & Tyrosine & $\begin{array}{c}\text { Fluorescence } \\
\text { under UV light }\end{array}$ & $\begin{array}{c}\text { MFAjor } \\
\text { ubiquinone }\end{array}$ \\
\hline L. taurinensis & + & - & $-/$ Red $(68 \%)$ & L. spiritensis serogroup 1 \\
L. spiritensis serogroup 1 & + & + & - & L. spiritensis serogroup 1 & Q-12 \\
L. spiritensis serogroup 2 & - & + & - & L. spiritensis serogroup 2 & Q-13 \\
L. rubrilucens & - & + & Red & L. rubrilucens & Q-12 \\
L. erythra serogroup 1 & + & + & Red & L. erythra serogroup 1 \\
L. erythra serogroup 2 & Variable & + & Red & L. rubrilucens & Q-12 \\
\hline
\end{tabular}


L. taurinensis is Turin I no. $1^{\mathrm{T}}\left(=\mathrm{ATCC} 700508^{\mathrm{T}}\right)$, which was isolated from a humidifier in the city of Turin (Italy). It has a $\mathrm{G}+\mathrm{C}$ content of $46 \mathrm{~mol} \%$.

\section{ACKNOWLEDGEMENTS}

We are grateful to Maddalena Castellani Pastoris (Instituto Superiore di Sanita, Roma, Italy) and Hans G. Trüper (University of Bonn, Bonn, Germany) for their help in designating the name of the new species, and to Morris Goldner (University of Laval, Canada) for editing the manuscript. We are also grateful to D. Blanc (CHU Vaudois, Lausanne, Switzerland), V. Drasar (Czech National Legionella Reference Laboratory, Vyskov, Czech Republic), $M$. Marques (Hospital of Santa Cruz, Carnaxide, Portugal) and C. Pelaz (Laboratorio de Legionella, Majadahonda, Spain) who provided us with some of the strains used in this study.

\section{REFERENCES}

Adeleke, A., Pruckler, J., Benson, R. F., Rowbotham, T., Halablab, M. \& Fields, B. (1996). Legionella-like amoebal pathogens phylogenetic status and possible role in respiratory disease. Emerg Infect Dis 2, 225-230.

Altschul, S. F., Madden, T. L., Schaffer, A. A., Zhang, J., Zhang, Z., Miller, W. \& Lipman, D. L. (1997). Gapped BLAST and PSI-BLAST: a new generation of protein database search programs. Nucleic Acids Res 25, 3389-3402.

Benson, R. F., Thacker, W. L., Lanser, J. A., Sangster, N., Mayberry, W. R. \& Brenner, D. J. (1991). Legionella adelaidensis, a new species isolated from cooling tower water. J Clin Microbiol 29, 1004-1006.

Benson, R. F., Thacker, W. L., Daneshvar, M. I. \& Brenner, D. J. (1996). Legionella waltersii sp. nov. and an unnamed Legionella genomospecies isolated from water in Australia. Int $J$ Syst Bacteriol 46, 631--634.

Birtles, R. J., Rowbotham, T. J., Raoult, D. \& Harrison, T. G. (1996). Phylogenetic diversity of intra-amoebal legionellae as revealed by $16 \mathrm{~S}$ rRNA gene sequence comparison. Microbiology 142, 3525-3530.

Bornstein, N., Marmet, D., Surgot, M. \& 9 other authors (1989). Legionella gratiana sp. nov. isolated from french spa water. Res Microbiol 140, 541-552.

Brenner, D. J., Steigerwalt, A. G. \& McDade, J. E. (1979). Classification of the Legionnaires' disease bacterium: Legionella pneumophila, genus novum, species nova, of the family Legionellaceae, family nova. Ann Intern Med 90, 656-658.

Brenner, D. J., McWhorter, A. C., Leete Knutson, J. K. \& Steigerwalt, A. G. (1982). Escherichia vulneris: a new species of Enterobacteriaceae associated with human wounds. J Clin Microbiol 15, 1133-1140.

Brenner, D. J., Steigerwalt, A. G., Gorman, G. W. \& 13 other authors (1985). Ten new species of Legionella. Int $J$ Syst Bacteriol 35, 50-59.

Brosius, J., Palmer, M. L., Kennedy, P. J. \& Noller, H. F. (1978). Complete nucleotide sequence of a 16S ribosomal RNA gene from Escherichia coli. Proc Natl Acad Sci USA 75, 4801-4805.

Cherry, W. B., Pittman, B., Harris, P. P., Hebert, G. A., Thomason, B. M., Thacker, L. \& Weaver, R. E. (1978). Detection of Legionnaires' disease bacteria by direct immunofluorescent staining. J Clin Microbiol 8, 329-338.

Crosa, J. H., Brenner, D. J. \& Falkow, S. (1973). Use of singlestrand specific nuclease for analysis of bacterial and plasmid deoxyribonucleic acid homo- and hetero-duplexes. $J$ Bacteriol 115, 904-911.

Dennis, P. J., Brenner, D. J., Thacker, W. L., Wait, R., Vesey, G., Steigerwalt, A. G. \& Benson, R. F. (1993). Five new Legionella species isolated from water. Int J Syst Bacteriol 43, 329-337.

Edelstein, P. H., Brenner, D. J., Moss, C. W., Steigerwalt, A. G., Francis, E. M. \& George, W. L. (1982). Legionella wadsworthii species nova: a cause of human pneumonia. Ann Intern Med $\mathbf{9 7}$, 809-813.

Fields, B. S. (1996). The molecular ecology of legionellae. Trends Microbiol 4, 286-290.

Fliermans, C. B. (1996). Ecology of Legionella: from data to knowledge with a little wisdom. Microb Ecol 32, 203-228.

Fliermans, C. B., Cherry, W. B., Orrison, L. H., Smith, S. J., Tison, D. L. \& Pope, D. H. (1981). Ecological distribution of Legionella pneumophila. Appl Environ Microbiol 41, 9-16.

Fry, N. K., Warwick, S., Saunders, N. A. \& Embley, T. M. (1991). The use of $16 \mathrm{~S}$ ribosomal RNA analysis to investigate the phylogeny of the family Legionellaceae. J Gen Microbiol 137, 1215-1222.

Gomez-Lus, P., Fields, B. S., Benson, R. F., Martin, W. T., O'Connor, S. P. \& Black, C. M. (1993). Comparison of arbitrarily primed polymerase chain reaction, ribotyping, and monoclonal antibody analysis for subtyping Legionella pneumophila serogroup 1. J Clin Microbiol 31, 1940-1942.

Grimont, P. A. D., Popoff, M. Y., Grimont, F., Coynault, C. \& Lemelin, M. (1980). Reproducibility and correlation study of three deoxyribonucleic-acid hybridization procedures. Curr Microbiol 4, 325-330.

Herwaldt, L. A., Gorman, G. W., McGrath, T. \& 12 other authors (1984). A new Legionella species, Legionella feeleii species nova, causes Pontiac fever in an automobile plant. Ann Intern Med 100, 333-338.

Hookey, J. V., Saunders, N. A., Fry, N. K., Birtles, R. J. \& Harrison, T. G. (1996). Phylogeny of Legionellaceae based on smallsubunit ribosomal DNA sequences and proposal of Legionella lytica comb. nov. for Legionella-like amoebal pathogens. Int $J$ Syst Bacteriol 46, 526-531.

Kaneko, T., Katoh, K., Fujimoto, M., Kumagai, M., Tamoka, J. \& Katayama-Fujimura, Y. (1986). Determination of the nucleotide composition of a deoxyribonucleic acid by high-performance liquid chromatography of its enzymatic hydrolysate: a review. $J$ Microbiol Methods 4, 229-240.

Lambert, M. A. \& Moss, C.W. (1989). Cellular fatty acid compositions and isoprenoid quinone contents of 23 Legionella species. J Clin Microbiol 27, 465-473.

Lo Presti, F., Riffard, S., Vandenesch, F., Reyrolle, M., Ronco, E., Ichai, P. \& Etienne, J. (1997). The first clinical isolate of Legionella parisiensis, from a liver transplant patient with pneumonia. $J$ Clin Microbiol 35, 1706-1709.

Marmur, J. \& Doty, P. (1962). Determination of the base composition of deoxyribonucleic acid from its thermal denaturation temperature. $J$ Mol Biol 5, 109-118.

Meunier, J.-R. \& Grimont, P. A. D. (1993). Factors affecting reproducibility of random amplified polymorphic DNA fingerprinting. Res Microbiol 144, 373-379.

Rowbotham, T. J. (1980). Preliminary report on the pathogenicity of Legionella pneumophila for freshwater and soil amoebae. J Clin Pathol 33, 1179-1183.

Sanger, F., Nicklen, S. \& Coulson, A. R. (1977). DNA sequencing with chain-terminating inhibitors. Proc Natl Acad Sci USA 74, 5463-5467. 
Stackebrandt, E. \& Goebel, B. M. (1994). Taxonomic note: a place for DNA-DNA reassociation and 16S rRNA sequence analysis in the present species definition in bacteriology. Int $J$ Syst Bacteriol 44, 846-849.

Stout, J. E., Yu, V. L. \& Best, M. G. (1985). Ecology of Legionella pneumophila within water distribution systems. Appl Environ Microbiol 49, 221-228.

Thacker, W. L., Benson, R. F., Staneck, J. L., Vincent, S. R., Mayberry, W. R., Brenner, D. J. \& Wilkinson, H. W. (1988). Legionella cincinnatiensis sp. nov. isolated from a patient with pneumonia. J Clin Microbiol 26, 418-420.

Thacker, W. L., Benson, R. F., Schifman, R. B., Pugh, E., Steigerwalt, A. G., Mayberry, W. R., Brenner, D. J. \& Wilkinson, H.W. (1989). Legionella tucsonensis sp. nov. isolated from a renal transplant recipient. J Clin Microbiol 27, 1831-1834.

Thacker, W. L., Dyke, J. W., Benson, R. F. \& 7 other authors (1992). Legionella lansingensis sp. nov. isolated from a patient with pneumonia and underlying chronic lymphocytic leukemia. $J$ Clin Microbiol 30, 2398-2401.

Ursing, J. B., Rossello-Mora, R. A., Garcia-Valdés, E. \& Lalucat, J. (1995). Taxonomic note: a pragmatic approach to the nomenclature of phenotypically similar genomic groups. Int J Syst Bacteriol 45, 604.

Verma, U. K., Brenner, D. J., Thacker, W. L. \& 7 other authors (1992). Legionella shakespearei sp. nov., isolated from cooling tower water. Int J Syst Bacteriol 42, 404-407.
Vickers, R. M. \& Yu, V. L. (1984). Clinical laboratory differentiation of Legionellaceae family members with pigment production and fluorescence on media supplemented with aromatic substrates. J Clin Microbiol 19, 583-587.

Vickers, R. M., Stout, J. E., Yu, V. L. \& Rihs, J. D. (1987). Manual of culture methodology for Legionella. Semin Respir Infect 2 , 274-279.

Wayne, L. G., Brenner, D. J., Colwell, R. R. \& 9 other authors (1987). International Committee on Systematic Bacteriology. Report of the ad hoc committee on reconciliation of approaches to bacterial systematics. Int J Syst Bacteriol 37, 463-464.

Wilkinson, H. W., Thacker, W. L., Benson, R. F., Polt, S. S., Brookings, E., Mayberry, W. R., Brenner, D. J., Gilley, R. G. \& Kirklin, J. K. (1987). Legionella birminghamensis sp. nov. isolated from a cardiac transplant recipient. J Clin Microbiol 25, 2120-2122.

Wilkinson, H. W., Drasar, V., Thacker, W. L., Benson, R. F., Schlinder, J., Potuznikova, B., Mayberry, W. R. \& Brenner, D. J. (1988). Legionella moravica sp. nov. and Legionella brunensis sp. nov. isolated from cooling-tower water. Ann Inst Pasteur Microbiol 139, 393-402.

Wilkinson, I. J., Sangster, N., Ratcliff, R. M., Mugg, P. A., Davos, D. E. \& Lanser, J. A. (1990). Problems associated with identification of Legionella species from the environment and isolation of six possible new species. Appl Environ Microbiol 56, 796-802. 